\title{
Biological Control of Phytopathogenic Fungi by Endophytic Actinomycetes Isolated from Maize (Zea mays L.)
}

\author{
Francisco Gheler Costa, Tiago Domingues Zucchi and Itamar Soares de Melo* \\ ${ }^{1}$ Laboratório de Microbiologia Ambiental; EMBRAPA, Meio Ambiente; Jaguariúna - SP - Brasil
}

\begin{abstract}
This work aimed a survey on the biodiversity of maize endophytic actinomycete, and an evaluation of their potential to control the phytopathogenic fungi. From several regions of São Paulo state, 40 strains were isolated from the healthy maize plants. The identification of these strains, based on morphological properties and fatty acid methyl ester (FAME) profile showed that most of them belonged to the Streptomyces genus. These isolates were first screened for the growth inhibition of phytopathogenic fungi and results showed that all the isolate were able to inhibit the development of at least one tested pathogen. Two selected isolates were then evaluated for the control of P. aphanidermatum in cucumber (Cucumis sativa L.) under greenhouse conditions. Isolate 16R3B was able to reduce up to $71 \%$ damping-off incidence whereas isolate 14F1D/2 reduced the disease incidence by $36 \%$. Dampingoff control in cucumber, mainly for the isolate 16R3B, suggested for its use in greenhouse cucumber producing fields and to be tested in field trials.
\end{abstract}

Key words: Endophytes, actinomycete, Streptomyces, Pythium aphanidermatum, dumping-off

\section{INTRODUCTION}

Currently, there is an increasing public concern regarding the continued use of agrichemicals to control the phytopathogenic fungi. This awareness relies mainly in the noxious effects of the pesticides on the environmental and human health (Cardoso et al. 2010). Several efforts have been made to find less hazardous options for controlling these plant pathogens among which the biological control using the microorganisms has been demonstrated to be a feasible alternative (Zucchi et al. 2008) but it is not widely used on commercial scale (Bressan 2003; Medeiros et al. 2012).

Among the biocontrol agents, endophytic microorganisms have raised special attention, mainly due to their crucial role on host-plant development (Firáková et al. 2007). Since these symbionts are systemically distributed in the plant via metabolic translocation (colonizing the same niche of the phytopathogens), they are interesting candidates for the biological control (Rai et al. 2007). Bacterial endophytes have been demonstrated to inhibit the plant pathogen development as well as to promote the growth of host plants (Hasegawa et al. 2006). A deeper understanding of the endophyte-host plant interaction can enhance the use of these microorganisms in the agriculture (Araújo et al. 2000; Lee et al. 2008). Currently, endophytic bacteria have been isolated from a huge variety of plant species but only a few crop species have been completely studied related to their endophytic community (Ryan et al. 2008). In maize, several reports have demonstrated its association with the endophytic bacteria (mainly Pseudomonas, Enterobacter and Bacillus) (Fisher et al. 1992; Mcinroy and Kloepper 1995;

*Author for correspondence: itamar.melo@embrapa.br 
Lodewyckx et al. 2002; Rai et al. 2007); however, only a few works have been made to isolate the endophytic actinomycete of this important crop.

Actinomycetes have been largely exploited mainly because their capability to produce bioactive compounds, such as antibiotics and lytic enzymes (El-Tarabily et al. 1997; Bérdy 2005; Clardy et al. 2006). In fact, antibiotics produced by the filamentous bacteria, mainly Streptomyces spp., have been reported to be able to inhibit the development of a broad range of phytopathogenic fungi and/or bacteria (Berg et al. 2001). Also, these compounds have often been related as one of the most important tools to control the soil-borne diseases (Buchenauer 1998) with low environmental impact and toxic effect for humans and animals, well-desired traits for new consumer's requirements (Cardoso et al. 2010).

One of these important soil-borne diseases is the root rot caused by Pythium aphanidermatum. This cosmopolitan pathogen can infect a huge variety of hosts, leading to severe economic losses, including monocots like maize and dicots cucumber (Postma et al. 2000; Zhang and Yang 2000; Veit et al. 2001). The control of $P$. aphanidermatum is usually difficult due to the lack of resistant cultivars and registered fungicides, which are only effective if used as preventive application (Postma et al. 2000). Root rot is generally a severe problem in high temperature and humidity regions, or in the greenhouse conditions. Due to its polyphagic nature, $P$. aphanidermatum can be used in screening programs as a reliable tool for enhancing the chance of selecting biocontrol agent for use in multiple crop systems. Thus, this work focussed on identifying the actinomycete endophyticallyassociated with maize (Zea mays L.) by using the culture-based approach to determine the ecological role of such interaction. Furthermore, the potential to control $P$. aphanidermatum using these endophytes were evaluated in cucumber seedlings under greenhouse conditions.

\section{MATERIALS AND METHODS}

\section{Plant Material}

Plant tissues (roots, leaves, stems) of maize (Zea mays L.) were collected from the rural area in four cities (Lins, Arthur Nogueira, Ouroeste and Salto Grande) in the São Paulo State, Brazil. All the areas had cultivated the same hybrid maize and the plants collected were around 60 days-old. The samples consisted of tree maize plants chosen randomly from the crop field.

\section{Isolation of Endophytic Actinobacteria Strains}

Plant tissues (leaves, stems and roots) were water washed to remove the soil residues and dust, and thereafter chopped in pieces of 8-12 $\mathrm{cm}$. All the samples were surface disinfected following Zucchi et al. (2008), then exposed to UV light for $10 \mathrm{~min}$, cut in smaller pieces and placed on the plates containing starch-casein-Agar medium (SCA; Küster and Williams, 1964) amended with nistatin $(50 \mu \mathrm{g} / \mathrm{mL})$. Inoculated plates were incubated at $28^{\circ} \mathrm{C}$ and actinobacterial growth was assessed at the intervals of 5 days until the $20^{\text {th }}$ day. The colonies were purified in Potato-Dextrose Agar (PDA; Beever and Bollard 1970) and stored at $4^{\circ} \mathrm{C}$.

\section{Actinobacteria Strains Characterization}

Each isolated strain was identified based on the whole-cell cellular fatty acids, derivatized to methyl esters (FAME) method (Sasser 1990) and analysed by a Hewllet Packard gas chromatograph model fitted with a fused silica capillary column ( $25 \mathrm{~m} \times 0.2 \mathrm{~mm}$ internal diameter). The interface was obtained by the ChemStation A.09.01 [1206] and MIDI Microbial Identification System 4.0 (Sherlock TSBA Library, MIDI ID, Inc., Newark, ED, USA) was used for phylogenetic analysis. The isolates with similarities indices (SIM) $\geq 0.3$ were considered positively identified, whereas the isolates with a SIM $<0.3$ were considered tentatively identified (Siciliano and Germida 1999; Misko and Germida 2002).

\section{Actinobacteria and Phytopathogenic Fungi Interaction}

This analysis was performed using five phytopathogenic fungi - Fusarium sp., Pythium aphanidermatum, Rhizoctonia solani, Sclerotinia sclerotiorum and Phytophthora parasitica - from the stock collection of the "Laboratório de Microbiologia Ambiental" at EMBRAPA, Jaguariúna, São Paulo State, Brazil. The antagonism assay with actinobacteria strains and phytopathogens were carried out in Petri dishes containing PDA medium. First, the actinobacterium was inoculated near the edge of the PDA plate. After that, a disc with $5 \mathrm{~mm}$ of diameter (removed from the edge of 
phytopathogenic colony) was placed at $3 \mathrm{~cm}$ distance from the actinobacterium inoculation point. The plates were incubated at $28^{\circ} \mathrm{C}$ for $5-7$ days.

\section{Actinobacteria Secondary Metabolites Extraction and Antibiosis Analysis}

The actinobacteria strains were inoculated in Potato-Dextrose (PD) medium and incubated in shaker $(150 \mathrm{rpm})$ at $28^{\circ} \mathrm{C}$ for seven days. The extractions of secondary metabolites were performed according to Canova et al. (2010) using ethyl acetate as solvent. The extracts were diluted to a final concentration of $20 \mu \mathrm{g} . \mu \mathrm{L}^{-1}$ and they were stored at $4^{\circ} \mathrm{C}$. An antibiosis assay was performed similarly as the antagonism assay. A total of $200 \mu \mathrm{g}$ of metabolite extract $\left(20 \mu \mathrm{g} . \mu \mathrm{L}^{-1}\right)$ was applied over a filter paper of $5 \mathrm{~mm}$ of diameter, placed on a Petri dish containing the PDA medium. A disc with $5 \mathrm{~mm}$ of diameter containing the phytopathogenic fungus was placed at $3 \mathrm{~cm}$ distance from the filter paper. The plates were incubated at $28^{\circ} \mathrm{C}$ for 5-7 days.

\section{Chitinolytic Analysis}

Isolates $16 \mathrm{R} 3 \mathrm{~B}$ and $14 \mathrm{~F} 1 \mathrm{D} / 2$ were inoculated in tryptic-soy broth (TSB), supplemented with $0.5 \%$ chitin and incubated under the constant agitation at $28^{\circ} \mathrm{C}$ for five days. Chitinolytic analysis was carried out following the CM-Chitin-RBV (Loewe) manufacturer protocol. Briefly, the cultures were centrifuged $\left(4^{\circ} \mathrm{C}, 14,000 \mathrm{xg}, 5 \mathrm{~min}\right)$ and $25 \mu \mathrm{L}$ of supernatant was incubated using 25 $\mu \mathrm{L}$ of CM-Chitin-RBV (Loewe), $50 \mathrm{~L}$ of Tris- $\mathrm{HCl}$ buffer $(100 \mathrm{mM}, \mathrm{pH} 7.5)$ at $45^{\circ} \mathrm{C}$ for $2 \mathrm{~h}$. The reaction was interrupted using $50 \mu \mathrm{L}$ of $\mathrm{HCl} 2 \mathrm{~N}$. The reading was performed using a wavelength of $550 \mathrm{~nm}$ and the enzyme was quantified following the method of Guzzo and Martins (1996). One unit (U) of the enzyme activity was defined by absorbance (abs) variation in one $\mathrm{ml}$ of substrate per min $\left(\mathrm{abs} \cdot \mathrm{ml}^{-1} \cdot \mathrm{min}^{-1}\right)$.

\section{Biological Control of Pythium aphanidermatum in Cucumber Seedlings}

The biological control of $P$. aphanidermatum was evaluated under greenhouse conditions. Seeds of cucumber were sowed in the substrate containing a mixture of sterilized soil and vermiculite (1:2). After 20 days, the seedlings were removed from the substrate and treated with the antagonists. The treated-seedlings were immersed (only the root) for $30 \mathrm{~min}$ in an antagonist suspension containing $10^{8} \mathrm{cfu}^{\mathrm{ml}}{ }^{-1}$. The control was treated with the sterilized water. In the phytopathogen treatments, the soil was infested with $P$. aphanidermatum keeping a proportion of $200 \mathrm{~g}$ of inoculum per 12 $\mathrm{L}$ of soil. After soil infection with the pathogen, an interval of $24 \mathrm{~h}$ was given before planting the seedlings. After these procedures, the seedlings were transplanted in $1 \mathrm{~L}$ pots and the treatments (T) used were: T1: Negative control; T2: Positive control (phytopathogen inoculation); T3: Fungicide control ( $3 \mathrm{~g} / \mathrm{L}$ of Metalaxyl - APRON 35PM); T4: 14F1D/2 strain $+P$. aphanidermatum and T5: 16R3B strain $+P$. aphanidermatum. Each treatment consisted of four repetitions with seven seedlings. After 14 days of the transplanting, the incidence of disease (damping-off) was evaluated for each treatment. This experiment was conducted twice. The data were subjected to a Tukey-test $(p<0.05)$, using the Sigma Stat program (Jandel Scientific, San Rafael, CA).

\section{RESULTS}

\section{Isolation and Characterization of Endophytic Actinobacteria}

A total of 40 endophytic strains were isolated from the maize plants, which included 20 from the leaves and 10 each from the stems and roots (Table 1). These isolates had morphological properties consistent to their classification in the order Actinomycetales and therefore, they were submitted to FAME analysis for the identification using a threshold of $30 \%$ similarity as exclusion criteria (Siciliano and Germida 1999; Misko and Germida 2002). Most of isolates were grouped within the Streptomyces genus. However, six strains (12R5/A, 21F2A, 8F2, 19C3D/B, 19R2C and $18 \mathrm{~F} 1 \mathrm{D} / \mathrm{A}$ ) demonstrated a low similarity index $(\mathrm{SIM}<0.3)$ with Streptomyces genus and other six strains (18C1A/B, 14R3, 21C3A1, 18F3B, 18C2D and $19 \mathrm{C} 3 \mathrm{~B} / \mathrm{D})$ were not effectively identified by FAME analysis. 
Table 1 - Endophytic actinobacteria community isolated from maize plant (positively or tentatively) identified by FAME analysis (Sherlock TSBA Library Version 4.0).

\begin{tabular}{|c|c|c|c|}
\hline Isolation Source & Strain & Identification $^{\text {a }}$ & Similarity Index ${ }^{b}$ \\
\hline \multirow{19}{*}{ LEAF } & 18F2C & Streptomyces albidoflavus & $45.5 \%$ \\
\hline & 18F2A & Streptomyces anulatus & $30.1 \%$ \\
\hline & 14F1C/B & Streptomyces californicus & $34.2 \%$ \\
\hline & 18F2G & Streptomyces halstedii & $56.8 \%$ \\
\hline & 11F2A, & Streptomyces halstedii & $53.8 \%$ \\
\hline & 15F3B & Streptomyces halstedii & $48.1 \%$ \\
\hline & 11F2A & Streptomyces halstedii & $44.4 \%$ \\
\hline & P4F1 & Streptomyces halstedii & $42.2 \%$ \\
\hline & 19F2C/1 & Streptomyces halstedii & $41.7 \%$ \\
\hline & 20F3F & Streptomyces halstedii & $41.6 \%$ \\
\hline & 19F2C/A & Streptomyces lavendulae & $57.3 \%$ \\
\hline & 18F3G/1 & Streptomyces lavendulae & $56.3 \%$ \\
\hline & 16F3B & Streptomyces lavendulae & $53.6 \%$ \\
\hline & 19F1C/2 & Streptomyces lavendulae & $46.4 \%$ \\
\hline & 14F1D/2 & Streptomyces violaceusniger & $68.3 \%$ \\
\hline & 14F1D/1 & Streptomyces violaceusniger & $50.2 \%$ \\
\hline & 18F1D/A & Streptomyces sp. & $25.8 \%$ \\
\hline & $8 F 2$ & Streptomyces sp. & $23.0 \%$ \\
\hline & 21F2A & Streptomyces sp. & $2.5 \%$ \\
\hline \multirow{6}{*}{ STEM } & 20C1A/B & Streptomyces californicus & $34.4 \%$ \\
\hline & 13C1B & Streptomyces halstedii & $63.8 \%$ \\
\hline & 13C1B & Streptomyces halstedii & $54.5 \%$ \\
\hline & 19C3B/C & Streptomyces lavendulae & $70.8 \%$ \\
\hline & $18 C 1 C / B$ & Streptomyces lavendulae & $65.8 \%$ \\
\hline & 19C3D/B & Streptomyces sp. & $25.4 \%$ \\
\hline \multirow{9}{*}{ ROOT } & 14R2K & Streptomyces exfoliatus & $42.6 \%$ \\
\hline & 8R20 & Streptomyces glaucescens & $41.0 \%$ \\
\hline & 9R1 & Streptomyces halstedii & $44.0 \%$ \\
\hline & 10R1 & Streptomyces halstedii & $39.0 \%$ \\
\hline & 16R3B & Streptomyces lavendulae & $62.3 \%$ \\
\hline & 17R1B/A & Streptomyces lavendulae & $60.6 \%$ \\
\hline & 9R11 & Streptomyces violaceusniger & $41.0 \%$ \\
\hline & 19R2C & Streptomyces sp. & $19.1 \%$ \\
\hline & 12R5/A & Streptomyces sp. & $3.4 \%$ \\
\hline
\end{tabular}

${ }^{\mathrm{a} I d e n t i f i c a t i o n ~ w a s ~ p e r f o r m e d ~ b y ~ f a t t y ~ a c i d ~ m e t h y l ~ e s t e r ~(F A M E) ~ a n a l y s i s ~ a n d ~ p r o c e s s e d ~ b y ~ M I D I ~ S h e r l o c k ~ s y s t e m . ~}{ }^{\mathrm{b}}$ Similarity Index: Positively identify, isolates identified with a SIM $\geq 0.3$; tentatively identify, isolates identified with a SIM $<0.3$ in Sherlock TSBA Library Version 4.0 (Misko and Germida 2002).

\section{Endophytic Actinobacteria and Phytopathogenic Fungi in Vitro Interactions} An antagonism screening test was performed to evaluate if the endophytic strains were able to inhibit the phytopathogenic fungi growth. The results showed that $S$. sclerotiorum, $P$. aphanidermatum, $R$. solani, Fusarium sp. and $P$. parasitica were inhibited by 47.5, 55.0, 62.5, 77.5 and $90 \%$ of the isolates, respectively (Table 2). The results also demonstrated that five strains isolated from the leaves $(18 \mathrm{~F} 3 \mathrm{G} / \mathrm{A}, 14 \mathrm{~F} 1 \mathrm{D} / 2$, $19 \mathrm{~F} 2 \mathrm{C} / \mathrm{A}, 14 \mathrm{~F} 1 \mathrm{C} / 3$ and $18 \mathrm{~F} 1 \mathrm{D} / \mathrm{A})$, three strains isolated from the roots (12R5/A, 10R1 and
19R2C) and one strain isolated from the stem $(18 \mathrm{C} 1 \mathrm{C} / \mathrm{B})$ was able to affect the mycelial growth of all the tested fungi. On the other hand, two strains isolated from the leaves $(11 \mathrm{~F} 2 \mathrm{~A}$ and $18 \mathrm{~F} 2 \mathrm{~A}$ ) were not able to inhibit any of the tested phytopathogens.

Although the strain 16R3B was not able to control $S$. sclerotiorum in the antagonism analysis, its secondary metabolites were able to inhibit the development of all the phytopathogenic fungi tested (data not shown). This strain along with the strain $14 \mathrm{~F} 1 \mathrm{D} / 2$ was chosen for further biological control analysis. 


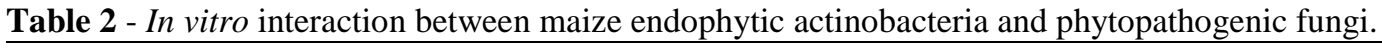

\begin{tabular}{|c|c|c|c|c|c|}
\hline \multirow[b]{2}{*}{ Isolates } & \multicolumn{5}{|c|}{$\begin{array}{l}\text { Phytopathogens } \\
\end{array}$} \\
\hline & $\begin{array}{c}\text { Pythium } \\
\text { aphanidermatum }\end{array}$ & $\begin{array}{c}\text { Rhizoctonia } \\
\text { solani }\end{array}$ & $\begin{array}{c}\text { Sclerotinia } \\
\text { sclerotiorum }\end{array}$ & $\begin{array}{l}\text { Phytophthora } \\
\text { parasitica }\end{array}$ & Fusarium sp. \\
\hline $\begin{array}{l}\text { 10R1, 18F3G/A, 14F1D/2, 12R5/A, } \\
\text { 18C1C/B, 19R2C, 14F1C/3, 19F2C/A, } \\
\text { 18F1D/A }\end{array}$ & $x_{1}$ & 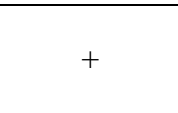 & 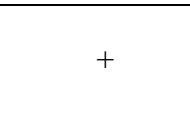 & 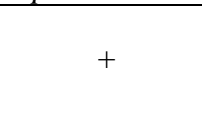 & + \\
\hline 17R1B/A, 8F2 & + & + & + & + & - \\
\hline $\begin{array}{l}\text { 16R3B, 20C1A/B, 19F2C/1, 19F1C/2, } \\
\text { 19C3B/D, P4F1, 9R1 }\end{array}$ & + & + & - & + & + \\
\hline $15 \mathrm{~F} 3 \mathrm{~B}, 18 \mathrm{~F} 2 \mathrm{G}$ & - & + & + & + & + \\
\hline 21C3A1, 20C1B, 21F2A, 19C3B/D' & - & + & - & + & + \\
\hline $20 \mathrm{~F} 3 \mathrm{~F}$ & + & - & - & + & + \\
\hline $18 \mathrm{~F} 2 \mathrm{C}$ & - & - & + & + & + \\
\hline 16F3B, 14R3, 19C3B/C, 9R11 & - & - & - & + & + \\
\hline 8R20, 19C3D/B, 14R2K & - & - & + & + & - \\
\hline $13 \mathrm{C} 1 \mathrm{~B}$ & - & + & - & + & - \\
\hline $13 \mathrm{C} 18,13 \mathrm{C} 1 \mathrm{~B}$ & + & - & - & + & - \\
\hline $18 \mathrm{C} 2 \mathrm{D}, 18 \mathrm{C} 1 \mathrm{~A} / \mathrm{B}$ & - & - & + & - & + \\
\hline $11 \mathrm{~F} 2 \mathrm{~A}, 18 \mathrm{~F} 2 \mathrm{~A}$ & - & - & - & - & - \\
\hline
\end{tabular}

Note: selected isolates are in bold.

\section{Chitinolytic Analysis}

Isolate $14 \mathrm{~F} 1 \mathrm{D} / 2$ displayed a $14.25 \mathrm{U}$ chitinase activity whereas isolate 16R3B showed $10.3 \mathrm{U}$ activity.

\section{Biocontrol of Pythium aphanidermatum in Cucumber Seedling}

Based on the in vitro screening tests, strains $14 \mathrm{~F} 1 \mathrm{D} / 2$ and $16 \mathrm{R} 3 \mathrm{~B}$ were selected for the biological control of $P$. aphanidermatum in cucumber seedlings, a host extremely susceptible to this pathogen. The fungicide control (phytopathogen + metalaxyl $3 \mathrm{~g}$ a.i./L) and the negative control (treatment without the phytopathogen) did not show any damping off incidence (Table 3). Besides, the positive control (treatment with the phytopathogen) demonstrated $98 \%$ of damping off. The actinobacterium strain 16R3B was more effective biocontrol agent against this phytopathogen.

Table 3 - "Damping off" incidence in cumcumber seedlings.

\begin{tabular}{cc}
\hline Treatment & Incidence (\%) \\
\hline Positive Control & $98.0 \mathrm{a}$ \\
14F1D/2 & $64.0 \mathrm{~b}$ \\
16R3B & $28.5 \mathrm{c}$ \\
Fungicide Control & $0.0 \mathrm{~d}$ \\
Negative Control & $0.0 \mathrm{~d}$ \\
\hline
\end{tabular}

Note: Values with the same letter are not significantly different according to Tukey test $(\mathrm{p}<0.05)$. Fungicide Control = Metalaxyl $(3 \mathrm{~g}$ a.i./L).
The incidence of damping-off was reduced to $28.5 \%$ when this strain was used. The strain 14F1D was less effective in which only $36.0 \%$ of disease control was achieved.

\section{DISCUSSION}

The lack of genera diversity (34 out 40 isolates were classified as Streptomyces by FAME analysis) found could be result of the media used for the isolation - known to be selective for a few species (Matsumoto et al. 1998) and/or due to regional difference with regards to the climate and soil. Indeed, environmental factors pose a highly influence for isolation of actinobacteria ( $\mathrm{Xu}$ et al. 1996; González et al. 2005). Besides, half of the isolates were recovered from maize leaves which indicated their ability to endophytically translocate inside the plant tissues. In a similar work, maize leaves were also the major reservoir for actinomycetes but representatives of three genera (Microbispora, Streptomyces and Streptosporangium) were recovered (Araújo et al., 2000). The divergence found between these communities of endophytic actinobacteria from the maize plants may be explained by the environmental differences between the two distant Brazilian regions were these studies were conducted: Northeast (tropical monsoon, Am; Araújo et al. 2000) and Southeast (humid subtropical, Cfa; this work). Nevertheless, these 
discrepancies highlight the need to conduct more research to understand how these endophytic communities interact with maize plants in different edaphoclimatic conditions.

Many works have reported positive findings using Streptomyces species for controlling different plant pathogens (Berg et al. 2001; Bérdy 2005; Zucchi et al. 2008; Zucchi et al. 2010). Traditionally, in vitro tests are the first step for screening a new biocontrol candidate with antagonistic activity against the target phytopathogens (Kunoh 2002). Also, antagonism and antibiosis procedures are usually the most suitable methods for screening the antibiotics producing organisms for further commercial exploration of these by-products (Pliego et al. 2011). Almost all the endophytic isolates $(95.1 \%)$ showed in vitro antagonistic effects against one, or more phytopathogenic fungi.

In an attempt to understand the mechanism involved in this in vitro interaction, the secondary metabolites produced by the endophytic actinobacteria were extracted and evaluated for their antibiosis effect. Strains 16R3B (S. lavendulae; $\mathrm{SIM}=62.3 \%)$ and $14 \mathrm{~F} 1 \mathrm{D} / 2(S$. violaceusniger; $\mathrm{SIM}=68.3 \%$ ) produced secondary metabolites, which were effective against all the phytopathogens tested and therefore, suggested that it might be one of the mechanisms used by these microorganisms to suppress the fungus development. Furthermore, both the strains produced chitinase, a well-known lytic enzyme used by the antagonist against the phytopathogenic fungi. The strains yielded almost the same amount of chitinase found for Micromonospora carbonacea and Streptomyces viridodiasticus (ElTarabily et al. 2000), which were high chitinase producers (El-Tarabily and Sivasithamparam 2006).

The efficiency of strain 16R3B for the biological control of $P$. aphanidermatum in cucumber seedlings $(71.5 \%)$ were similar to those found by Elad and Chet (1987). These authors evaluated the effect of 130 rhizobacterial strains isolated from several commercial crops against Pythium sp. and demonstrated that the incidence of damping-off decreased by up to $67 \%$. This reduction was due to a competition between the microorganisms (biocontrol agent and phytopahtogen). In fact, other mechanisms besides the antibiosis and competition could be involved in controlling the phytopatogens by filamentous bacterial species, such as systemic resistance (Hasegawa et al. 2006; Conn et al. 2008). Actinomycetes producing lytic enzymes potentially hyperparasite the vegetative and/or reproductive structures of Pythium spp. (ElTarabily et al. 1997). The selected strains used in this study were isolated from the leaf $(14 \mathrm{~F} 1 \mathrm{D} / 2)$ and root (16R3B) (Table 1). Although the highest number of endophytes was found in the leaves, the root isolate was the more effective against $P$. aphanidermatum. This could drive further efforts to better understand the interactions between the actinomycete endophytic community from the maize root and soilborne phytopathogens for selecting the biocontrol candidates.

The strain 14F1/D2, which had also shown promising results in laboratory conditions, failed when used in the greenhouse conditions. These discrepancies between in vitro and in vivo assays results have been discussed by many authors (Deacon and Berry 1993). One possible explanation for these differences could be that the biocontrol agent might be artificially favoured under the laboratory conditions (Weller 1988). This must be taken in to account before considering any isolate as a potential biocontrol agent. Despite of that the in vitro screening was effective in selecting a possible biocontrol candidate, isolate 16R3B. The results found under greenhouse conditions by this isolate highlighted its potential as a biocontrol agent to reduce the damping-off caused by $P$. aphanidermatum in this planting system.

\section{CONCLUSION}

The endophytic isolate 16R3B showed promising results in vitro and in vivo tests and therefore, this isolate could be considered as a potential candidate for further biological control programs of $P$. aphanidermatum.

\section{ACKNOWLEDGMENTS}

This work was supported by FAPESP (Fundação de Amparo à Pesquisa do Estado de São PauloBrazil), CNPq (Conselho Nacional de Desenvolvimento Cientifico e Tecnologico-Brazil) and CAPES (Coordenação de Aperfeiçoamento de Pessoal de Nivel Superior-Brazil). 


\section{REFERENCES}

Araújo JM, Silva AC, Azevedo JL. Isolation of endophytic actinomycetes from roots and leaves of maize (Zea may L.). Braz Arch Biol Techn. 2000; 43: 447-451.

Beever RE, Bollard EG. Nature of stimulation of fungal growth by potato extract. J Gen Microbiol. 2000; 60: 273-279.

Bérdy J. Bioactive microbial metabolites. $J$ antibiotics. 2000; 58: 1-26.

Berg G, Marten P, Minkwitz A, Bruckner S. Efficient biological control of fungal plant diseases by Streptomyces sp DSMZ 12424. Z Pflanzenk Pflanzen. 2001; 108: 1-10.

Bressan W. Biological control of maize seed pathogenic fungi by use of actinomycetes. BioControl. 2003; 48: 233-240.

Buchenauer H. 1998. Biological control of soil-borne diseases by rhizobacteria. Z Pflanzenk Pflanzen. 105: 329-348.

Canova SP, Petta T, Reyes LF, Zucchi TD, Moraes LAB, Melo IS. Characterization of lipopeptides from Paenibacillus sp. (IIRAC30) suppressing Rhizoctonia solani. World J Microb Biot. 2010; 26: 2241-2247.

Cardoso RA, Pires LTA, Zucchi TD, Zucchi FD, Zucchi TMAD. Mitotic crossing-over induced by two commercial herbicides in diploid strains of the fungus Aspergillus nidulans. Gen Mol Res. 2010; 9: 231-238.

Clardy J, Fischbach MA, Walsh CT. New antibiotics from bacterial natural products. Nature Biotechnol. 2006; 24: 1541-1550.

Conn VM, Walker AR, Franco CMM. 2008. Endophytic actinobacteria induce defense pathways in Arabidopsis thaliana. Mol Plant-Microbe In. 2008; 21: 208-218.

Deacon JW, Berry LA. Biocontrol of soil-borne plantpathogens: Concepts and their application. Pestic Sci. 1993; 37: 417-426.

El-Tarabily KA, Hardy GESJ, Sivasithamparam K, Hussein AM, Kurtboke DI. The potential for the biological control of cavity-spot disease of carrots, caused by Pythium coloratum, by streptomycete and non-streptomycete actinomycetes. New Phytol. 1997; 137: 495-507.

El-Tarabily KA, Sivasithamparam K. Nonstreptomycete actinomycetes as biocontrol agents of soil-borne fungal plant pathogens and as plant growth promoters. Soil Biol Biochem. 2006; 38: 1505-1520.

El-Tarabily KA, Soliman MH, Nassar AH, Al-Hassani HA, Sivasithamparam K, McKenna F, Hardy GES. Biological control of Sclerotinia minor using a chitinolytic bacterium and actinomycetes. Plant Pathology. 2000; 49: 573-583.

Elad Y, Chet I.. Possible role of competition for nutrients in biocontrol of Pythium damping-off by bacteria. Phytopathology. 1987; 77: 190-195.
Firáková S, Šturdíková M, Múčková M. Bioactive secondary metabolites produced by microorganisms associated with plants. Biologia. 2007; 62: 251-257.

Fisher PJ, Petrini O, Scott HML. The distribution of some fungal and bacterial endophytes in maize (Zea mays L.). New Phytol. 1992; 122: 299-305.

González I, Ayuso-Sacido A, Anderson A, Genilloud O. Actinomycetes isolated from lichens: evaluation of their diversity and detection of biosynthetic gene sequences. Fems Microbiol Ecol. 2005; 54: 401-415.

Guzzo SD, Martins EMF. Local and systemic induction of $\beta$-1,3-glucanase and chitinase in coffee leaves protected against Hemileia vastatrix by Bacillus thuringiensis. J Phytopathol. 1996; 144: 449-454.

Hasegawa S, Meguro A, Shimizu M, Nishimura T, Kunoh H. Endophytic actinomycetes and their interactions with host plants. Actinomycetologica. 2006; 20: 72-81.

Kunoh H. Endophytic actinomycetes: attractive biocontrol agents. J Gen Plant Pathol. 2002; 68: 249252.

Küster E, Williams ST. Selection of media for isolation of streptomycetes. Nature. 1964; 202: 928-929.

Lee SO, Choi GJ, Choi YH, Jang KS, Park DJ, Kim CJ, et al. Isolation and characterization of endophytic actinomycetes from Chinese cabbage roots as antagonists to Plasmodiophora brassicae. J Microbiol Biotechnol. 2008; 18: 1741-1746.

Lodewyckx C, Vangronsveld J, Porteous F, Moore ERB, Taghavi S, Mezgeay M, et al. Endophytic bacteria and their potential applications. Crit Rev Plant Sci. 2002; 21: 583-606.

Matsumoto A, Takahashi Y, Mochizuki M, Seino A, Iwai Y, Omura S. Characterization of actinomycetes isolated from fallen leaves. Actinomycetologica. 1998; 12: 46-48.

Medeiros FHV, Martins SJ, Zucchi, TD, Melo IS, Batista LR, Machado JC. Biological control of mycotoxin-producing molds. Ciênc. Agrotec. 2012; 36: 483-497.

Mcinroy JA, Kloepper JW. Survey of indigenous bacterial endophytes from cotton and sweet corn. Plant Soil. 1995; 173: 337-342.

Misko AL, Germida JJ. Taxonomic and functional diversity of pseudomonads isolated from the roots of field-grown canola. Fems Microbiol Ecol. 2002; 42: 399-407.

Postma J, Willemsen-de Klein MJEIM, van Elsas JD. Effect of the indigenous microflora on the development of root and crown rot caused by Pythium aphanidermatum in cucumber grown on rockwool. Phytopathol. 2000; 90: 125-133.

Pliego C, Ramos C, de Vicente A, Cazorla F. Screening for candidate bacterial biocontrol agents against soilborne fungal plant pathogens. Plant Soil 2011; 340: 505-520. 
Rai R, Dash PK, Prasanna BM, Singh A. Endophytic bacterial flora in the stem tissue of a tropical maize (Zea mays L.) genotype: isolation, identification and enumeration. World J Microb Biot. 2007; 23: 853858.

Ryan RP, Germaine K, Franks A, Ryan DJ, Dowling DN. Bacterial endophytes: recent developments and applications. Fems Microbiol Lett. 2008; 278: 1-9.

Sasser M. Identification of bacteria by gas chromatography of cellular fatty acids. Newark, DE: MIDI Inc.; 1990.

Siciliano SD, Germida JJ. Taxonomic diversity of bacteria associated with the roots of field-grown transgenic Brassica napus cv. Quest, compared to the non-transgenic $B$. napus cv. Excel and B. rapa cv. Parkland. Fems Microbiol Ecol. 1999; 29: 263-272.

Veit S, Wörle JM, Nürnberger T, Koch W, Seitz HU. A novel protein elicito (PaNie) from Pythium aphanidermatum induces multple defense responses in carrot, Arabidopsis and tobacco. Plant Physiol. 2001; 127: 832-841.
Weller DM. Biological control of soilborne plant pathogens in the rhizosphere with bacteria. Annual Review of Phytopathology. 1988; 26: 379-407.

$\mathrm{Xu}$ LH, Li QR, Jiang CL. Diversity of soil actinomycetes in Yunnan, China. Appl Environ Microb. 1996; 62: 244-248.

Zhang BQ, Yang XB. Pathogenicity of Pythium populations from corn-soybean rotation fields. Plant Disease. 2000; 84: 94-99.

Zucchi TD, Almeida LG, Dossi FCA, Cônsoli FL. Secondary metabolites produced by Propionicimonas sp. (ENT-18) induce histological abnormalities in the sclerotia of Sclerotinia sclerotiorum. BioControl. 2010; 55: 811-819.

Zucchi TD, Moraes LA, Melo IS. Streptomyces sp. ASBV-1 reduces aflatoxin accumulation by Aspergillus parasiticus in peanut grains. J Appl Microbiol. 2008; 105: 2153-2160. 